\title{
The use of Fourier-transform infrared spectroscopy to predict cheese yield and nutrient recovery or whey loss traits from unprocessed bovine milk samples
}

\author{
A. Ferragina, C. Cipolat-Gotet, A. Cecchinato, ${ }^{1}$ and G. Bittante \\ Department of Agronomy, Food, Natural Resources, Animals and Environment, University of Padova, Viale dell'Università 16, 35020 Legnaro, \\ Italy
}

\begin{abstract}
Cheese yield is an important technological trait in the dairy industry in many countries. The aim of this study was to evaluate the effectiveness of Fouriertransform infrared (FTIR) spectral analysis of fresh unprocessed milk samples for predicting cheese yield and nutrient recovery traits. A total of 1,264 model cheeses were obtained from 1,500-mL milk samples collected from individual Brown Swiss cows. Individual measurements of 7 new cheese yield-related traits were obtained from the laboratory cheese-making procedure, including the fresh cheese yield, total solid cheese yield, and the water retained in curd, all as a percentage of the processed milk, and nutrient recovery (fat, protein, total solids, and energy) in the curd as a percentage of the same nutrient contained in the milk. All individual milk samples were analyzed using a MilkoScan FT6000 over the spectral range from 5,000 to 900 wavenumber $\times \mathrm{cm}^{-1}$. Two spectral acquisitions were carried out for each sample and the results were averaged before data analysis. Different chemometric models were fitted and compared with the aim of improving the accuracy of the calibration equations for predicting these traits. The most accurate predictions were obtained for total solid cheese yield and fresh cheese yield, which exhibited coefficients of determination between the predicted and measured values in cross-validation (1-VR) of 0.95 and 0.83 , respectively. A less favorable result was obtained for water retained in curd $(1-\mathrm{VR}=0.65)$. Promising results were obtained for recovered protein $(1-\mathrm{VR}=$ $0.81)$, total solids $(1-\mathrm{VR}=0.86)$, and energy $(1-\mathrm{VR}=$ $0.76)$, whereas recovered fat exhibited a low accuracy $(1-\mathrm{VR}=0.41)$. As FTIR spectroscopy is a rapid, cheap, high-throughput technique that is already used to collect standard milk recording data, these FTIR calibrations for cheese yield and nutrient recovery highlight additional potential applications of the technique in the
\end{abstract}

Received May 16, 2013.

Accepted August 13, 2013.

${ }^{1}$ Corresponding author: alessio.cecchinato@unipd.it dairy industry, especially for monitoring cheese-making processes and milk payment systems. In addition, the prediction models can be used to provide breeding organizations with information on new phenotypes for cheese yield and milk nutrient recovery, potentially allowing these traits to be enhanced through selection. Key words: mid-infrared spectroscopy, cheese yield, cheese-making, whey losses

\section{INTRODUCTION}

Percentage cheese yield (\% $\mathbf{C Y}$; the quantity of cheese obtained from a given quantity of milk processed, expressed as percentage) is the most important economic trait for the dairy industry in many countries and, indirectly, for the definition of price of milk. Unfortunately, this and other traits cannot be routinely measured on a large scale for milk payment systems or direct genetic improvement at the population level.

Several studies have described procedures for model cheese production (Hicks et al., 1981; Hurtaud et al., 1995; Cologna et al., 2009). These procedures include accurate methods for evaluating \% CY, but the methods are expensive, time-consuming, and not applicable for routine application. Furthermore, we are only aware of a few studies reporting the use of model cheeses for the evaluation of individual milk samples (Hurtaud et al., 1995; Melilli et al., 2002; Wedholm et al., 2006), and only one of these model cheese-making procedures was applied on a large number of individual samples (Cipolat-Gotet et al., 2013). This latter procedure yielded a complete nutrient profile for the cheese-making process with the quantification of 3 different \%CY parameters: the classic ratio between the weight of curd produced and the weight of the milk processed; the weight of dry curd versus that of the milk processed; and the weight of water retained in the curd versus that of the milk processed. The model cheese-making procedure of Cipolat-Gotet et al. (2013) also allowed the recovery coefficients (REC) of individual milk components to be determined from curd, quantifying the ratios between the curd contents of fat, protein, total solids, and 
energy versus the content of the corresponding nutrient in the milk processed. The deviations of the REC from unity correspond to the whey losses of individual milk nutrients. Moreover, the measurements of $\% \mathrm{CY}$ and daily milk yield allowed the authors to calculate the daily cheese yields of individual cows in $\mathrm{kg} \times \mathrm{d}^{-1}$ (dCY).

Using the same data set, Bittante et al. (2013) found that the phenotypic correlation between the REC of fat and protein was weak, as were the correlations between these 2 traits and the fat and protein contents of milk. This indicates that the fat and protein contents alone do not fully explain \%CY variations or the real economic value of milk. Moreover, the same authors found that all of the \%CY, dCY, and REC (and, thus, also the whey losses) exhibited exploitable genetic variations with heritability estimates similar to (dCY) or greater than (\%CY and REC) the estimates for milk yield and similar to the heritability of milk quality traits (with the exception of the REC of protein, which was much more heritable than the protein content of milk; Bittante et al., 2013). As expected, \%CY of curd and total solids showed high genetic correlations with the fat and protein contents of milk, whereas the other traits (especially REC of fat and protein) did not (Bittante et al., 2013). These findings indicate that the inclusion of milk fat and protein contents in the selection indices of dairy populations as a tool for the indirect selection for $\mathrm{CY}$ is effective, but it cannot explain all the genetic variability of these traits, and it is much less useful for the indirect selection of REC and nutrient losses in whey.

Several formulae have been reported for predicting \%CY from milk components (Emmons et al., 1990, 1993; Emmons and Modler, 2010), and some that are specific for kinds of cheese (Fenelon and Guinee, 1999). For these formulae to be useful in the indirect selection of dairy populations, the milk composition must be known (several analyses are required), and it is speculated that these formulas are seldom more effective than the direct use of milk composition data. However, whereas many instruments currently support the rapid analysis of milk composition, instruments that directly predict \%CY and REC are not yet available.

The absorbance of milk samples at individual wavelengths in the medium infrared (MIR) region has been demonstrated to be associated with many chemical bonds (Barbano and Lynch, 2006; Brandt et al., 2010; Karoui et al., 2010) and to be heritable (Bittante and Cecchinato, 2013). The prediction of milk composition using Fourier-transform infrared (FTIR) spectroscopy has become largely routine in the dairy industry and milk recording laboratories (ICAR, 2012). These instruments have also been tested for the prediction of other technological properties of milk-particularly coagulation - and this promising application appears to be nearly ready for routine application (Dal Zotto et al. 2008; Cecchinato et al., 2009; Bittante et al., 2012). Some studies have also investigated the possibility of using near infrared technology for at-line monitoring of milk coagulation and curd syneresis in dairy plants (O'Callaghan et al., 2002; Fagan et al., 2007a, b; Leitner et al., 2011). Other studies have assessed the use of near infrared technology to predict the curd moisture content, whey fat content, and curd yield at the end of syneresis as a function of processing time during syneresis (Fagan et al., 2008). However, no previous study has assessed the possibility of using FTIR spectroscopy to directly predict \%CY and REC (or whey losses) from raw milk samples collected for milk recording or milk payment systems.

The present study sought to evaluate the effectiveness of FTIR spectroscopy for the prediction of 3 individual cheese yields (fresh curd weight, curd solids, and curd water as percentages of the weight of milk processed) and 4 milk component recoveries (or whey losses), expressed as the protein, fat, solid, and energy contents of the curd (or whey) as a percentage of the corresponding nutrient (protein, fat, solids, and energy, respectively) contents of the milk processed. For these aims, we examined the FTIR spectra of individual milk samples from 1,264 Brown Swiss cows previously used for individual model cheese production by CipolatGotet et al. (2013).

\section{MATERIALS AND METHODS}

\section{Field Data}

The present study is part of the Cowplus projects of the autonomous province of Trento, Italy. The sampling procedure has previously been described in detail by Cipolat-Gotet et al. (2012) and Cecchinato et al. (2013). A total of 1,264 Brown Swiss cows from 85 herds located in Trento Province were sampled once during evening milking. The cows represented different parities (1-5), DIM (5-449), and production levels $(24.3 \pm 7.9$ $\left.\mathrm{kg} \times \mathrm{d}^{-1}\right)$. Within a given day, only 1 herd was sampled. Two milk subsamples per cow were collected and immediately refrigerated at $4^{\circ} \mathrm{C}$ without any preservative. One subsample $(50 \mathrm{~mL})$ was transported to the milk quality laboratory of the Breeders Federation of Trento Province (Trento, Italy) for composition analysis. The other subsample $(2,000 \mathrm{~mL})$ was transferred to the cheese-making laboratory of the Department of Agronomy, Food, Natural Resources, Animals and Environment of the University of Padova for model cheese fabrication. All samples were processed for analyses and model cheese fabrication within $20 \mathrm{~h}$ from collec- 
tion. Data on the cows, herds, and single test-day milk yield were provided by the Superbrown Consortium of Bolzano and Trento (Italy), and pedigree information was supplied by the Italian Brown Swiss Cattle Breeders Association (Verona, Italy).

\section{Model Cheese-Making Procedure}

Individual milk samples were analyzed for fat, protein, and casein percentages using a MilkoScan FT6000 (Foss, Hillerød, Denmark). Somatic cell count was obtained from the Fossomatic FC counter (Foss) and was then converted to SCS by means of logarithm transformation (Ali and Shook, 1980). The procedure used for individual model cheese production was based on that described by Cologna et al. (2009), which showed good repeatability. A detailed description of the modified cheese-making procedure was previously reported (Cipolat-Gotet et al., 2013). Briefly, 1,500 mL of milk was heated to $35^{\circ} \mathrm{C}$ in a stainless steel microvat, supplemented with thermophilic starter culture, mixed with rennet, and controlled for coagulation time. The resulting curd from each vat was cut, drained, shaped in wheels, pressed, salted, weighed, sampled, and analyzed. The whey collected from each vat was also weighed, sampled, and analyzed.

\section{Trait Definitions}

All of the traits were measured based on the weights (g) and chemical compositions of milk and whey, as detailed by Cipolat-Gotet et al. (2013). The measured traits were

- cheese yield (\% $\left.\mathbf{C Y} \mathbf{Y}_{\mathbf{C U R D}}\right)$ as grams of curd $\times$ 100/g of milk;

- TS cheese yield (\% $\left.\mathbf{C Y}_{\text {Solids }}\right)$ as (grams of milk TS - grams of whey TS) $\times 100 / g$ of milk;

- water cheese yield (\% CY $\left.\mathbf{Y}_{\text {WATER }}\right)$ as (grams of milk water - grams of whey water $) \times 100 / g$ of milk;

- fat recovery $\left(\mathbf{R E C}_{\mathrm{FAT}}\right)$ as (grams of milk fat grams of whey fat) $\times 100 / \mathrm{g}$ of milk fat;

- protein recovery (REC $\mathbf{R R O T E I N}_{\text {Pros }}$ ) (grams of milk protein - grams of whey protein) $\times 100 / g$ of milk protein;

- TS recovery ( $\mathbf{R E C}_{\text {Solids }}$ ) as (grams of milk TS grams of whey TS) $\times 100 / g$ of milk TS; and

- energy recovery ( $\mathbf{R E C}_{\text {ENERGY }}$ ) as (milk energy whey energy) $\times 100 /$ milk energy.

\section{MIR Spectral Acquisition}

All individual milk samples were analyzed using a MilkoScan FT6000 (Foss Electric, Hillerød, Denmark) over the spectral range from 5,000 to 900 wavenumber $\times \mathrm{cm}^{-1}$; the spectra were stored as absorbance using the transformation absorbance $=\log (1 /$ transmittance). Two spectral acquisitions were carried out for each sample, and the results were averaged before data analysis.

\section{Data Analysis and Chemometric Models}

Calibration models were developed using the WinISI II software (Infrasoft International LLC, State College, PA) and carried out using modified partial least square regression (MPLS) as the chemometric algorithm. Spectra were used without pretreatment, as well as with various pretreatments, including standard normal variate (SNV), standard normal variate and detrend, multiplicative scatter correction, and first and second derivatives. Moreover, FTIR spectra were analyzed across the whole interval (from 5,000 to 900 wavenumber $\times \mathrm{cm}^{-1}$ ) or without the 2 portions known to be characterized by a very high phenotypic variability: the transition region between the short-wave to midwave infrared (3,669-3,052 $\mathrm{cm}^{-1}$; SWIR-MWIR) and the mid-wavelength infrared region (MWIR-2), from 1,698 to 1,586 wavenumber $\times \mathrm{cm}^{-1}$ (Bittante and Cecchinato, 2013), as shown in Figure 1. A combination of these pretreatments was also used for a total of 19 models for each parameter.

Anomalous spectra were detected using the Mahalanobis distance (global $\mathrm{H}$ ) from the population mean; samples that exhibited large distance (global $\mathrm{H}>10$ ) were considered H-outliers. Samples for which the difference between the reference and predicted value was much larger than the standard error of cross-validation $\left(\mathbf{S E C}_{\mathbf{c v}}\right)$ were considered T-outliers (the established T value was 2.5). Two steps were used to eliminate outliers. First, a cross-validation using 4 groups of samples from the calibration set was used to assess the robustness of calibration. Second, to compare the effectiveness of calibration models, we calculated the $\mathrm{SEC}_{\mathrm{cv}}$, the coefficient of determination of cross-validation (1-VR), the standard error of prediction corrected for the bias, and the ratio of prediction to deviation (RPD) that is the ratio of $\mathrm{SD}$ of reference values to the $\mathrm{SEC}_{\mathrm{CV}}$, the RPD larger than 2 indicates a good calibration (Karoui et al., 2006).

\section{RESULTS AND DISCUSSION}

\section{Characteristics of the Infrared Spectrum of Milk}

Table 1 presents descriptive statistics for the milk quality traits, cheese yield, and nutrient recoveries. The milk samples used for model cheese fabrication exhib- 


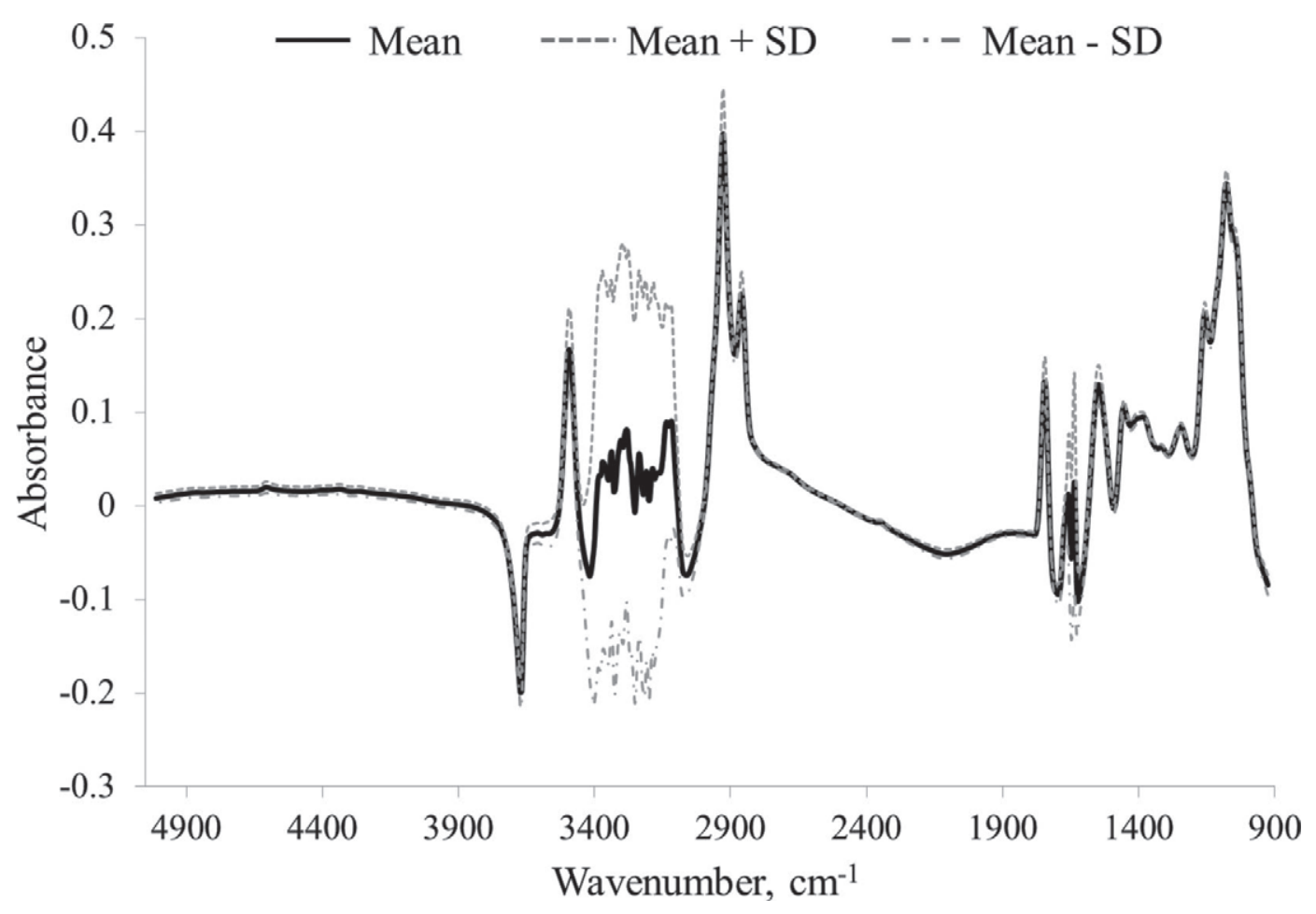

Figure 1. Plots showing the absorbance of milk samples $\left(\log \mathrm{T}^{-1}\right.$; solid black line represents the average, whereas the 2 gray lines represent the average $\pm \mathrm{SD})$.

ited large variability in terms of chemical composition, $\% \mathrm{CY}$, and REC. A comprehensive discussion of these traits was previously published by Cipolat-Gotet et al. (2013).

In classifying the infrared spectrum of milk into 5 regions, Bittante and Cecchinato (2013) identified the regions of 3,052 to 3,669 wavenumber $\times \mathrm{cm}^{-1}$ (SWIRMWIR; the transition region between near infrared and MIR) and 1,586 to $1,698 \mathrm{~cm}^{-1}$ (MWIR-2) as being particularly important because they harbor the typical peaks due to water absorption $(\approx 3,920,3,490$, 3,280 , and 1,645 wavenumber $\left.\times \mathrm{cm}^{-1}\right)$. These peaks can significantly increase the variability of absorbance (Figure 1), creating interference that can reduce the accuracy of calibrations. For this reason, the MWIR-2 and SWIR-MWIR spectral regions were omitted when we performed all calibrations used for the present study, except for the prediction of protein recovery (Table 2).

These 2 regions are important for the absorbance peaks typical of other chemical bonds. In fact, the SWIR-MWIR region contains wavelengths characteristic of the absorbances for $\mathrm{C}=\mathrm{CH}_{2}$ bonds, the $\mathrm{O}-\mathrm{H}$ bonds typical of alcohols, phenols, and carboxylic acids, and the N-H bonds of primary and secondary amines (the major absorption peaks of amines I and II are at 3,500 to 3,400 and $>3,000$ wavenumber $\times \mathrm{cm}^{-1}$, respectively). The MWIR-2 region includes absorption peaks related to the acyclic and conjugated $\mathrm{C}-\mathrm{C}, \mathrm{C}=$ $\mathrm{C}, \mathrm{C}=\mathrm{O}, \mathrm{C}-\mathrm{N}$, and $\mathrm{N}-\mathrm{H}$ bonds, as well as those for proteins (Karoui et al., 2011), with the typical absorption peaks for amides I and II falling at 1,700 to 1,600 wavenumber $\times \mathrm{cm}^{-1}$ and 1,600 to 1,500 wavenumber $\times \mathrm{cm}^{-1}$, respectively (Hewavitharana and van Brakel, 1997; Curley et al., 1998; Etzion et al., 2004). The latter peculiarity explains why, despite the interference due to water absorption, the inclusion of these 2 regions allowed us to obtain better calibrations for predicting protein recovery (Table 2 ).

The band that provides direct information about a specific constituent and its molecular structure is found between 400 and 4,000 wavenumber $\times \mathrm{cm}^{-1}$ (Etzion et al., 2004; Karoui et al., 2010). The present study also considered information from the short wave infrared region found between 5,000 and 3,673 wavenumber $\times$ $\mathrm{cm}^{-1}$, which typically does not present relevant peaks and thus has been omitted from some studies (Karoui et al., 2011). In the MWIR-1 region (3,048 to 1,701 wavenumber $\times \mathrm{cm}^{-1}$ ), the most important peaks are located between 3,000 and 2,800 wavenumber $\times \mathrm{cm}^{-1}$ and are due to fat absorption (Karoui et al., 2010; Karoui et al., 2011), particularly that of fat B (Lynch et al., 2006; Kaylegian et al., 2009). For fat A, the typi- 
Table 1. Descriptive statistics of milk and whey quality traits of individual percentage cheese yields and of milk components recoveries from 1,264 milk samples/model cheeses

\begin{tabular}{|c|c|c|c|c|}
\hline Trait & Mean & SD & Minimum & Maximum \\
\hline \multicolumn{5}{|c|}{ Milk quality traits, $\%$} \\
\hline Fat & 4.38 & 0.90 & 1.06 & 11.89 \\
\hline Protein & 3.75 & 0.43 & 2.60 & 5.77 \\
\hline Casein & 2.88 & 0.32 & 1.94 & 4.51 \\
\hline Lactose & 4.77 & 0.24 & 3.80 & 5.40 \\
\hline TS & 13.89 & 1.05 & 10.75 & 21.10 \\
\hline SCS, units & 2.98 & 1.86 & -1.32 & 10.03 \\
\hline \multicolumn{5}{|c|}{ Whey quality traits, $\%$} \\
\hline Fat & 0.53 & 0.22 & 0.08 & 1.78 \\
\hline Protein & 0.97 & 0.16 & 0.56 & 1.68 \\
\hline Lactose & 5.15 & 0.21 & 4.22 & 5.76 \\
\hline TS & 7.79 & 0.33 & 6.65 & 9.33 \\
\hline \multicolumn{5}{|l|}{ Cheese yield ${ }^{1}$} \\
\hline$\% \mathrm{CY}_{\mathrm{CURD}}$ & 15.04 & 1.89 & 10.23 & 20.58 \\
\hline$\% \mathrm{CY}_{\text {SOLIDS }}$ & 7.22 & 0.93 & 4.64 & 10.40 \\
\hline$\% \mathrm{CY}_{\text {WATEB }}$ & 7.80 & 1.28 & 4.43 & 11.72 \\
\hline \multicolumn{5}{|c|}{ Nutrient recovery, ${ }^{2} \%$} \\
\hline REC $_{\text {PROTEIN }}$ & 78.07 & 2.41 & 70.51 & 85.25 \\
\hline REC $_{\text {FAT }}$ & 89.87 & 3.58 & 76.77 & 98.12 \\
\hline $\mathrm{REC}_{\text {SOLIDS }}$ & 52.05 & 3.58 & 42.01 & 63.34 \\
\hline REC $_{\text {ENERGY }}$ & 67.31 & 3.32 & 57.64 & 77.64 \\
\hline
\end{tabular}

${ }_{1} \% \mathrm{CY}_{\mathrm{CURD}}=$ weight of fresh curd as percentage of weight of milk processed; $\% \mathrm{CY}_{\text {SOLIDS }}=$ weight of curd solids as percentage of weight of milk processed; $\% \mathrm{CY}_{\mathrm{WATER}}=$ weight of curd water as percentage of weight of milk processed

${ }^{2} \mathrm{REC}_{\text {PROTEIN }}=$ protein of the curd as percentage of the protein of the milk processed; $\mathrm{REC}_{\mathrm{FAT}}=$ fat of the curd as percentage of the fat of the milk processed; $\mathrm{REC}_{\text {SoLIDS }}=$ solids of the curd as percentage of solids of the milk processed; $\mathrm{REC}_{\mathrm{ENERGY}}=$ energy of the curd as percentage of the energy of the milk processed.

cal absorption peak is at $\approx 1,740$ wavenumber $\times \mathrm{cm}^{-1}$. Lastly, the region of transition between the mid- and long-wave infrared (called the fingerprint region and located between 1,582 and 930 wavenumber $\times \mathrm{cm}^{-1}$ ) contains the peaks corresponding to the absorbances of many chemical compounds (carbohydrates and organic

Table 2. Fitting statistics of predictions models for individual cheese yields and milk components recoveries

\begin{tabular}{|c|c|c|c|c|c|c|c|c|c|c|}
\hline Trait & $\mathrm{n}^{1}$ & MPLS $^{2}$ & Math $^{3}$ & SD & $\mathrm{SEC}^{4}$ & $\mathrm{R}^{2}$ & $\mathrm{SEC}_{\mathrm{cv}}{ }^{5}$ & $1-\mathrm{VR}^{6}$ & $\operatorname{SEP}(C)^{7}$ & $\mathrm{RPD}^{8}$ \\
\hline$\% \mathrm{CY}_{\mathrm{CURD}}$ & 1,205 & 10 & $\mathrm{~W}, 1,10,4,1$ & 1.84 & 0.71 & 0.85 & 0.75 & 0.83 & 0.97 & 2.45 \\
\hline \multicolumn{11}{|c|}{ Nutrient recovery, ${ }^{10} \%$} \\
\hline REC $_{\text {PROTEIN }}$ & 1,208 & 16 & A, $1,4,4,1$ & 2.34 & 0.87 & 0.86 & 1.02 & 0.81 & 1.33 & 2.29 \\
\hline $\mathrm{REC}_{\mathrm{FAT}}$ & 1,181 & 12 & $\mathrm{~W}, 1,10,4,1$ & 3.03 & 2.17 & 0.49 & 2.32 & 0.41 & 3.02 & 1.31 \\
\hline
\end{tabular}

${ }^{1} \mathrm{n}=$ number of samples used in the calibration after removing outlier.

${ }^{2}$ MPLS $=$ number of modified partial least square components

${ }^{3}$ Math $=$ mathematical treatments of the spectral data where the letters indicate the spectral range used for calibration $(\mathrm{A}=$ all the spectrum $5,011-930 \mathrm{~cm}^{-1} ; \mathrm{W}=$ spectra segments used $5,011-3,673 \mathrm{~cm}^{-1}, 3,048-1,701 \mathrm{~cm}^{-1}$, and $1,582-930 \mathrm{~cm}^{-1}$; SNV = standard normal variate). The first number is the order of the derivative, the second number is the segment length in data points over which the derivative was taken, and the third and fourth numbers are the segment length for first and second smoothing, respectively.

${ }^{4} \mathrm{SEC}=$ standard error of calibration

${ }^{5} \mathrm{SEC}_{\mathrm{cv}}=$ standard error of cross-validation

${ }^{6} 1-\mathrm{VR}=$ coefficient of determination of cross-validation

${ }^{7} \mathrm{SEP}(\mathrm{C})=$ standard error of prediction corrected for the bias.

${ }^{8} \mathrm{RPD}=$ ratio of prediction to deviation $\left(\mathrm{SD} / \mathrm{SEC}_{\mathrm{CV}}\right)$.

${ }^{9} \% \mathrm{CY}_{\mathrm{CURD}}=$ weight of fresh curd as percentage of weight of milk processed; $\% \mathrm{CY}_{\text {SOLIDS }}=$ weight of curd solids as percentage of weight of milk processed; $\% \mathrm{CY}_{\text {WATER }}=$ weight of curd water as percentage of weight of milk processed.

${ }^{10} \mathrm{REC}_{\mathrm{PROTEIN}}=$ protein of the curd as percentage of the protein of the milk processed; $\mathrm{REC}_{\mathrm{FAT}}=$ fat of the curd as percentage of the fat of the milk processed; $\mathrm{REC}_{\text {SOLIDS }}=$ solids of the curd as percentage of solids of the milk processed; $\mathrm{REC}_{\text {ENERGY }}=$ energy of the curd as percentage of the energy of the milk processed. 
acids); for example, lactose has an absorbance peak at $\approx 1,040$ wavenumber $\times \mathrm{cm}^{-1}$ (Kaylegian et al. 2009; Lynch et al. 2006).

Figure 2 presents the loadings of the first 2 principal components used to predict \% $\mathrm{CY}_{\text {CURD }}$, with the SWIRMWIR and MWIR-2 regions omitted (Figure 2a), and those of $\mathrm{REC}_{\text {PROTEIN }}$, which were based on the entire spectrum (Figure 2b).

\section{Prediction of Cheese Yield}

The results from the best prediction models of each trait are presented in Table 2. The best predictions for all of the \%CY measurements were those that omitted the SWIR-MWIR and MWIR-2 regions of the spectrum. The first derivative pretreatment was applied for all of them to increase the resolution of spectra peaks highlighting the signal due to the chemical composition, and only $\mathrm{CY}_{\text {WATER }}$ required standardization (SNV). To compare the models in terms of accuracy, we used 1-VR, the $\mathrm{SEC}_{\mathrm{CV}}$, the numbers of MPLS components, and the RPD. For $\% \mathrm{CY}_{\mathrm{CURD}}, 3.8 \%$ outliers were observed using the Mahalanobis distance, 10 MPLS components were used, the $\mathrm{SEC}_{\mathrm{CV}}$ was \pm 0.75 percentage points, the $1-\mathrm{VR}$ was 0.83 , and the RPD 2.45. The prediction of $\% \mathrm{CY}_{\text {SOLIDS }}$ yielded the highest $1-\mathrm{VR}$ value $(0.95)$ and RPD (4.24) among the examined traits, it had $6 \%$ outliers and an $\mathrm{SEC}_{\mathrm{CV}}$ of only \pm 0.21 percentage points, and used 10 MPLS components. Lastly, \%CY $\mathrm{CY}_{\text {WATER }}$ had a lower value of 1-VR (0.65), used 12 MPLS components, and was found to have $3.7 \%$ outliers and a $\mathrm{SEC}_{\mathrm{CV}}$ of \pm 0.71 percentage points; the RPD value was 1.70 .

Figure 3 shows scatter plots of the predicted versus measured \% CY. The good predictions obtained for $\% \mathrm{CY}_{\mathrm{CURD}}$ and $\% \mathrm{CY}_{\text {SOLIDS }}$ were not unexpected because of the high number of measured traits used for prediction (Rutten et al., 2010). As noted previously, the absorbances of several wavelengths from the infrared bands of the electromagnetic spectrum are related to the chemical bonds typical of fats and proteins (Bittante and Cecchinato, 2013). Mid-infrared absorption information has been used to predict the fat and protein contents of milk because of the high precision and repeatability ensured by these secondary methods of analysis. Two main methodologies have been used: the first based on the absorbance at specific wavelengths (Kaylegian et al., 2006; Lynch et al., 2006) and the second examining the entire spectrum (or large portions of it) through the Fourier-transform strategy (Hewavitharana and van Brakel, 1997; Etzion et al., 2004). Both of these techniques have reached the quality standards necessary to be approved by the ICAR (2012). As cheese yield primarily depends on the milk fat and protein contents, the promising results obtained in the present work were as expected. This relationship may also explain why the predictive ability of FTIR calibration equations was higher for $\% \mathrm{CY}_{\text {SOLIDS }}$ than for $\% \mathrm{CY}_{\mathrm{CURD}}$ (1-VR: 0.95 vs. 0.83 , respectively; Table $2)$. The $\% \mathrm{CY}_{\text {SOLIDS }}$ are almost exclusively composed of fats and proteins (casein) retained in the curd, and these substances represent most of the fat and protein contents of the milk. In contrast, the water retained in the curd is only a small proportion of the water in milk, and (unlike caseins and whey proteins) cannot be chemically differentiated. The $\% \mathrm{CY}_{\text {WATER }}$ cannot be estimated by the quantity of water present in the milk, but rather by the hydration characteristics of retained proteins and the quantity of solutes. Given these indirect relationships between the water retained in the curd and the presence of chemical bonds measurable by infrared spectra, the lower accuracy of FTIR

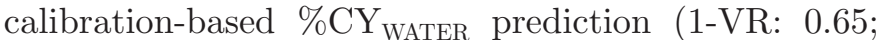
Table 2) is reasonable. We would also expect that the accuracy of $\% \mathrm{CY}_{\mathrm{CURD}}$ prediction would be intermediate between those of $\% \mathrm{CY}_{\text {WATER }}$ and $\% \mathrm{CY}_{\text {SOLIDS }}$, as it represents their sum.

The next crucial question was whether the FTIR spectrum-based prediction of $\% \mathrm{CY}_{\text {SOLIDS }}$ was simply a different representation of the constant proportion of its fat and protein contents (and thus failed to add any meaningful new information) versus a more precise estimation of the fat and protein (and also other substances, such as minerals and glucose) retained in the curd. This question could only be answered by testing the ability of our FTIR-based technique to predict not only the quantity of different nutrients present in the milk sample, but also their ability to be retained in the curd when the milk is processed for cheese-making.

\section{Prediction of Whey Losses and Nutrient Recovery from Milk to Curd}

The best prediction model (Table 2) for $\mathrm{REC}_{\text {PRoteIN }}$ used the entire spectrum, whereas those for the other measures excluded the MWIR-2 and SWIR-MWIR regions. The first derivative was applied for all of the REC models as spectra pretreatments to increase the resolution of spectra peaks highlighting the signal due to the chemical composition, and $\mathrm{REC}_{\text {SOLIDS }}$ also used standardization (SNV).

The number of MPLS components used for RECPROTEIN prediction was high (16) with $3.2 \%$ outliers observed, a $\mathrm{SEC}_{\mathrm{CV}}$ of \pm 1.02 percentage points, and a $1-\mathrm{VR}$ of 0.81 ; the $R P D$ value was 2.29 . The $\mathrm{REC}_{\mathrm{FAT}}$ had the lowest 1-VR value (0.41) and RPD (1.31), a high $\mathrm{SEC}_{\mathrm{CV}}( \pm 2.32$ percentage points $)$ and $4.4 \%$ outliers, and used 12 MPLS components. The $\mathrm{REC}_{\text {SOLIDS }}$ had a high value $1-\mathrm{VR}(0.86)$, an $\mathrm{SEC}_{\mathrm{CV}}$ of \pm 1.27 percentage 
FERRAGINA ET AL.

a)

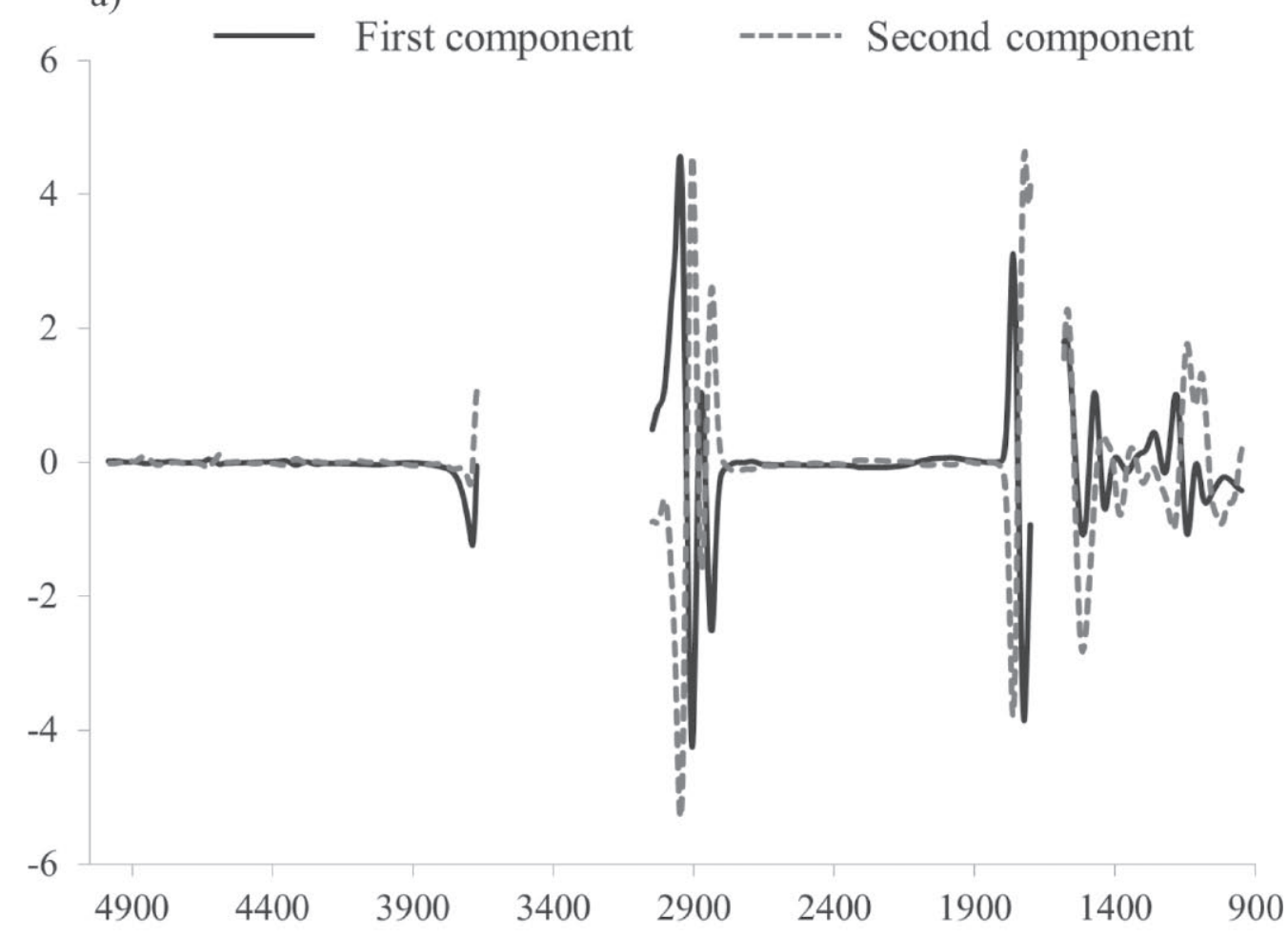

b)

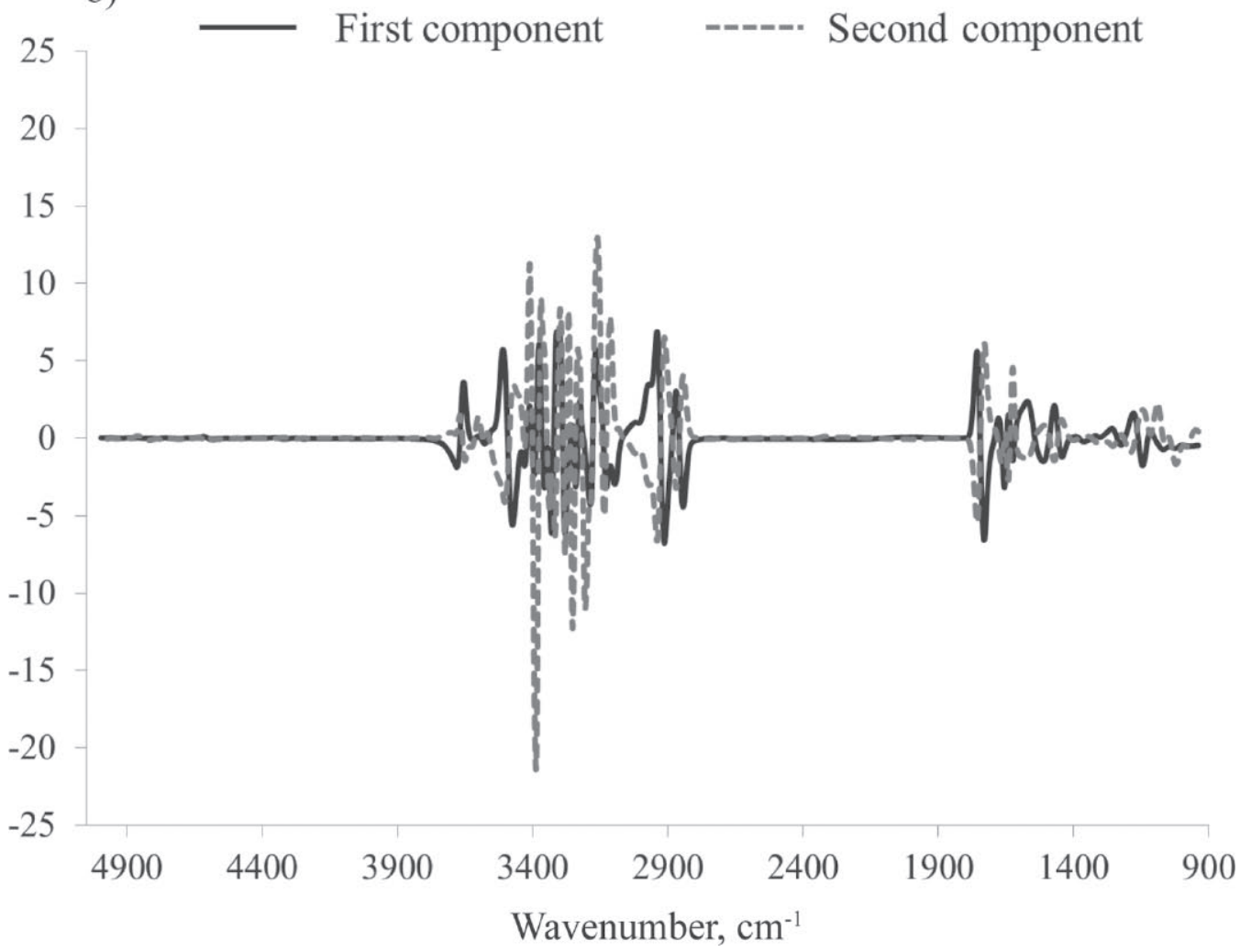

Figure 2. First and second loading relative to (a) the prediction of percentage cheese yield and (b) the prediction of protein recovery from milk to curd. 
a)

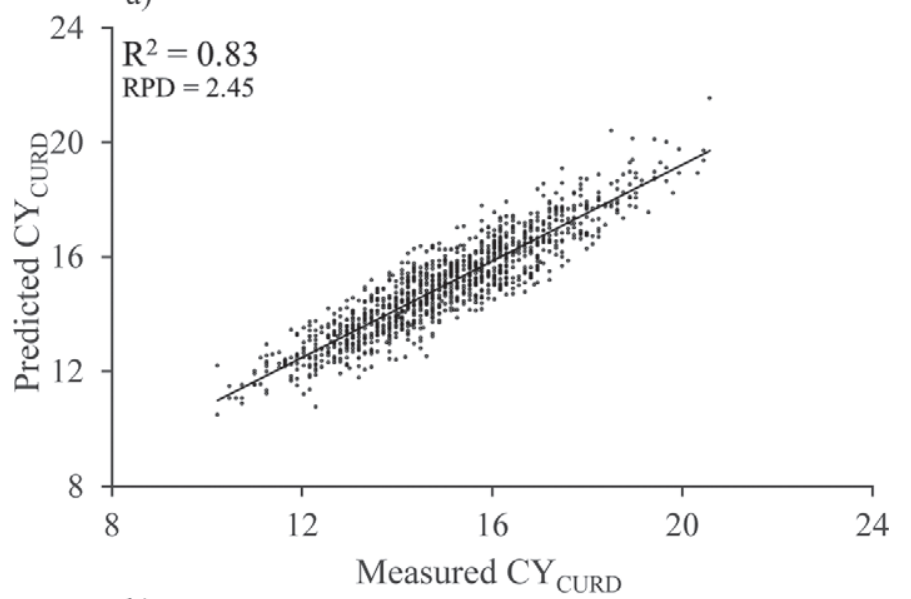

b)

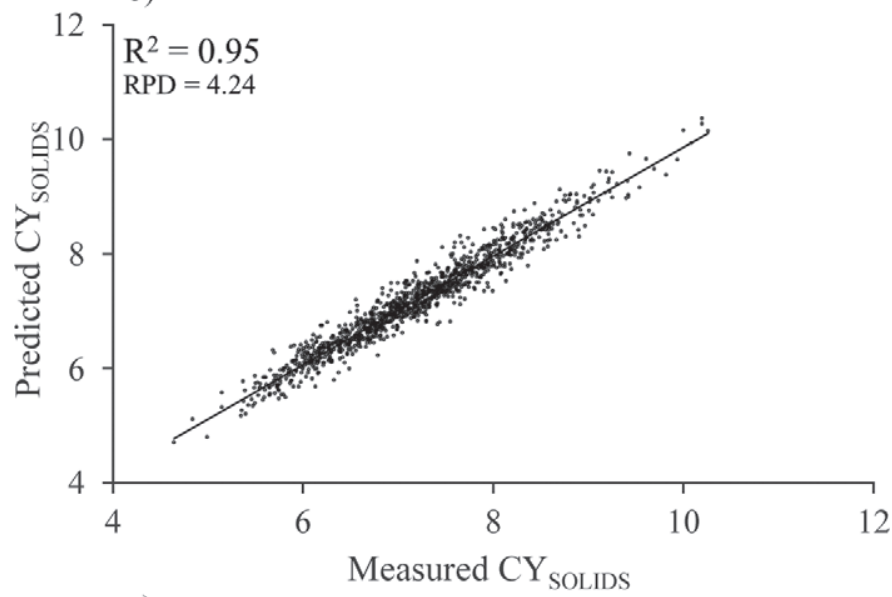

c)

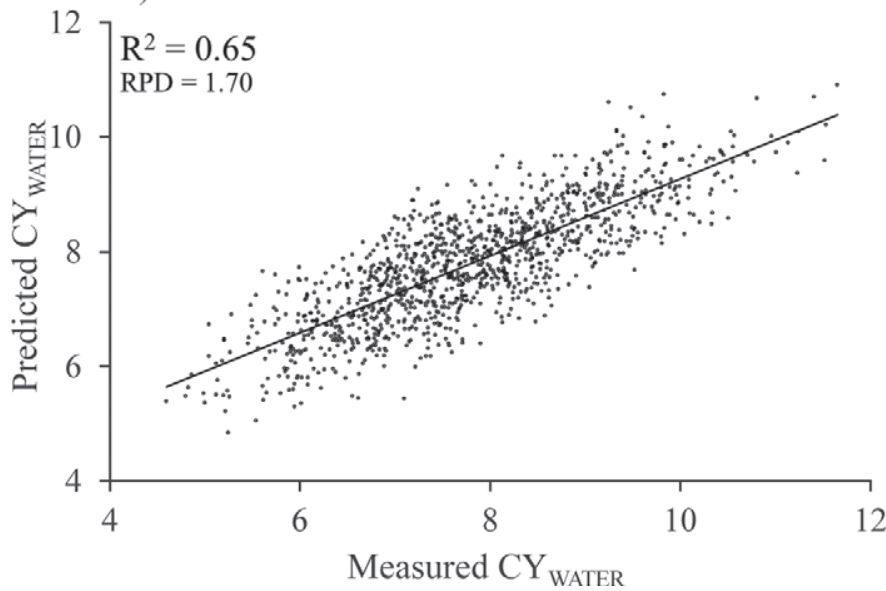

Figure 3. Scatter plots of predicted versus measured values of percentage (a) weight of fresh curd as percentage of weight of milk processed ( $\left.\mathrm{CY}_{\mathrm{CURD}}\right)$, (b) weight of curd solids as percentage of weight of milk processed ( $\mathrm{CY}_{\text {SOLIDS }}$ ), and (c) weight of curd water as percentage of weight of milk processed $\left(\mathrm{CY}_{\mathrm{WATER}}\right) . \mathrm{RPD}=$ ratio of prediction to deviation. points and $5.5 \%$ outliers, and used 11 MPLS components; the RPD value was 2.69. Lastly, $\mathrm{REC}_{\text {ENERGY }}$ had $5.4 \%$ outliers, used 12 MPLS components, and had a $1-\mathrm{VR}$ of 0.76 , an RPD of 2.04 , and an $\mathrm{SEC}_{\mathrm{CV}}$ of \pm 1.5 percentage points. Figure 4 displays scatter plots of the predicted versus measured REC values. These results clearly show that FTIR spectrum-based calibrations are valuable tools for predicting the retention of nutrients in the curd after cheese-making (with the partial exception of fat recovery).

From the chemical point of view, the fat lost in the whey does not strongly differ from that retained in the curd (Kaylegian et al., 2009). However, FTIR spectroscopy may be used to predict the FA profiles of milk (Soyeurt et al., 2006; Rutten et al., 2009; Afseth et al., 2010; De Marchi et al., 2011; Soyeurt et al., 2011), and fat retention depends more on physical properties, such as fat globule size (Couvreur et al., 2007), curd-firming rate, curd cutting, and so on (Aleandri et al., 1989; Johnson et al., 2001; Malacarne et al., 2006).

The $\mathrm{REC}_{\text {PROTEIN }}$ values present a somewhat different scenario, because the protein retained in the curd mainly consists of caseins, which differ somewhat from whey proteins in their chemical compositions. It should be noted that the previous attempts to predict specific milk protein fractions (Van Der Ven et al., 2002; Arnould et al., 2009; Bonfatti et al., 2011; Rutten et al., 2011) yielded accuracy parameters that were generally inferior to the present calibration for $\mathrm{REC}_{\text {PROTEIN }}$. Moreover, Cipolat-Gotet et al. (2013) found that the phenotypic variability of $\mathrm{REC}_{\text {PROTEIN }}$ was larger than that of the casein index, even though the average values of the 2 traits are almost identical. Finally, Bittante et al. (2013) estimated a much higher heritability value for $\mathrm{REC}_{\text {PROTEIN }}$ than that obtained for the protein content of milk. Thus, $\mathrm{REC}_{\text {PROTEIN }}$ clearly represents more than just the protein fraction.

The accuracy of predicting $\mathrm{REC}_{\text {SOLIDS }}$ is not intermediate between those of $\mathrm{REC}_{\text {PROTEIN }}$ and $\mathrm{REC}_{\mathrm{FAT}}$, but this may be explained by noting that this parameter depends not only on fat and protein, but also on lactose and minerals and their relative proportions. It seems that the FTIR can discriminate between the different solids of milk that are lost and the solids that are retained in the curd, thereby increasing the accuracy of the $\mathrm{REC}_{\text {SOLIDS }}$ prediction. Finally, considering the higher energy value of fat versus protein, the lower ability of FTIR calibration to predict fat recovery versus protein recovery explains the lower accuracy of $\mathrm{REC}_{\text {ENERGY }}$ compared with $\mathrm{REC}_{\text {SOLIDS }}$.

\section{CONCLUSIONS}

The present study investigated the feasibility of using calibrations based on the FTIR spectrum of fresh un- 


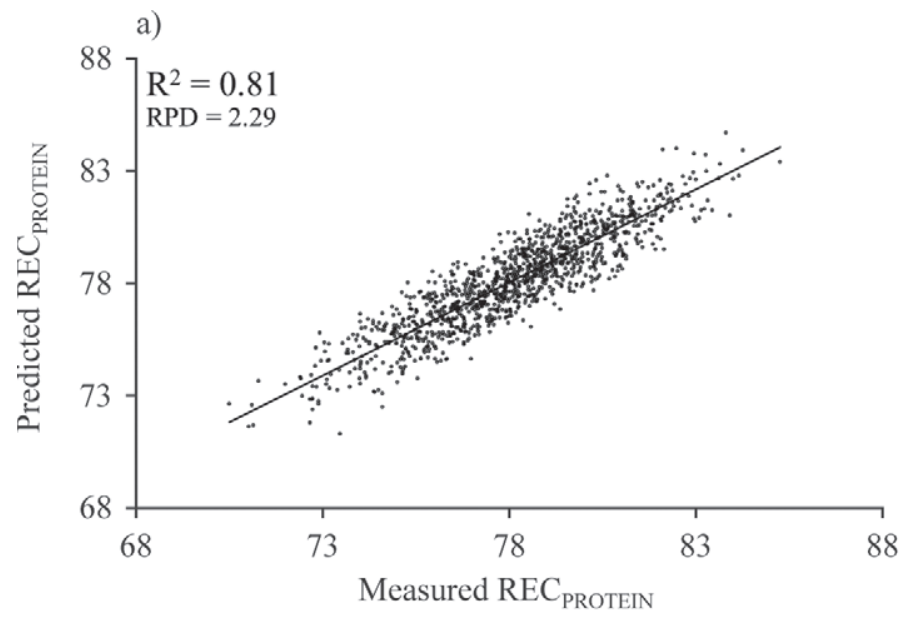

b)

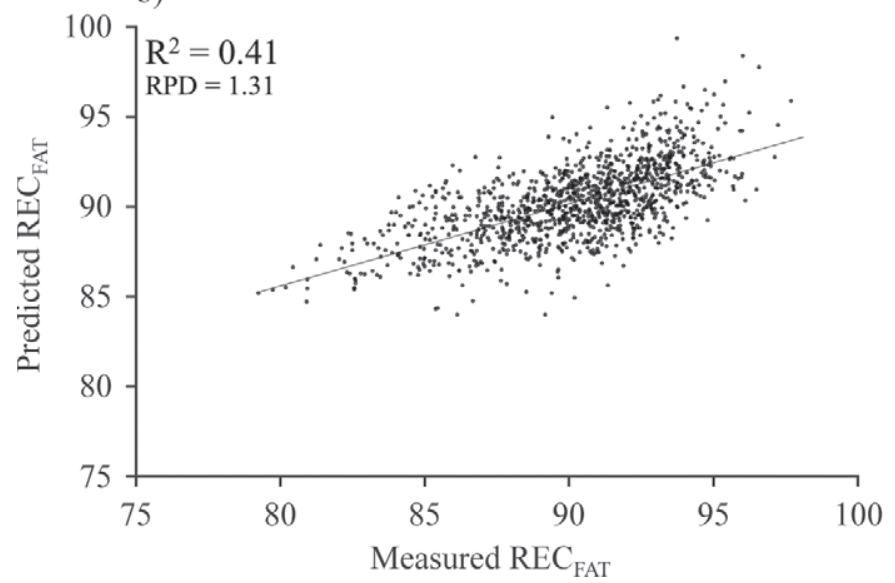

c)

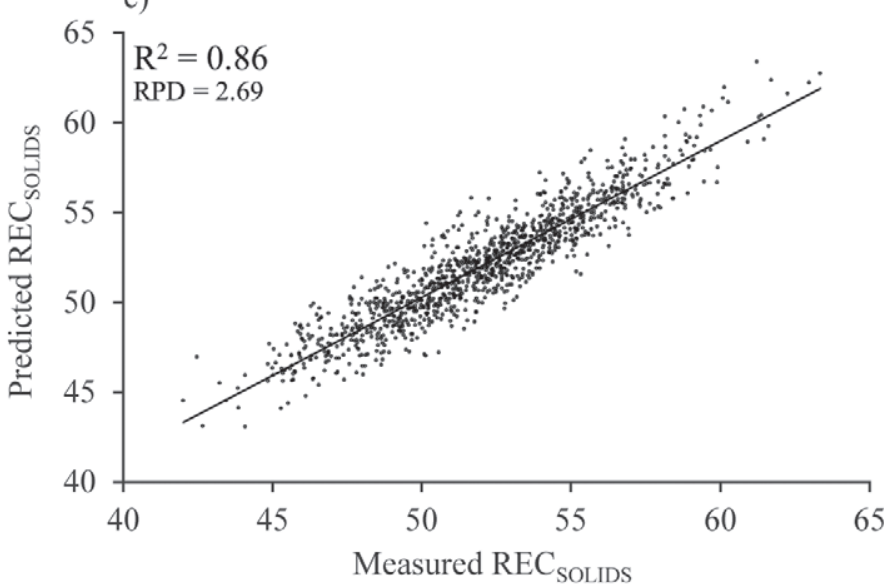

d)

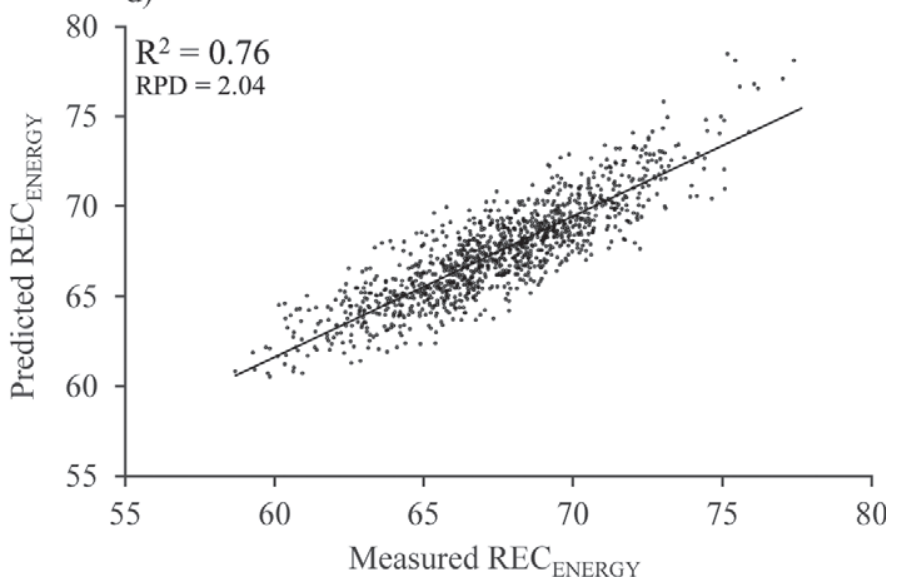

Figure 4. Scatter plots of predicted versus measured values of (a) protein of the curd as percentage of the protein of the milk processed ( $\mathrm{REC}_{\text {PRotein }}$ ), (b) fat of the curd as percentage of the fat of the milk processed $\left(\mathrm{REC}_{\mathrm{FAT}}\right)$, (c) solids of the curd as percentage of solids of the milk processed $\left(\mathrm{REC}_{\mathrm{SOLIDS}}\right)$, and $(\mathrm{d})$ energy of the curd as percentage of the energy of the milk processed $\left(\mathrm{REC} \mathrm{ENERGY}_{\mathrm{E}}\right)$. RPD $=$ ratio of prediction to deviation.

processed milk samples to predict cheese yields, which are expressed as the weight of fresh curd, curd TS, and water retained in the curd as percentage of the weight of the milk processed for cheese-making. The obtained results showed that the estimation of the TS cheese yield was highly accurate. The FTIR calibrations were also capable of predicting (albeit with a lower accuracy) the amount of water retained in the curd, and thus the cheese yield in its most commonly known definition (weight of curd versus weight of milk). With respect to the indirect estimation of cheese yield based on milk composition, especially on the fat and protein (casein) contents, we found that FTIR calibrations have not only the potential to predict the main nutrient contents in milk but also their specific retentions in cheese or losses in the whey (especially for proteins, TS, and energy). Nevertheless, further research is needed to actually compare the results yielded by FTIR with those achievable with the use of prediction formulas based only on milk composition. Fourier-transform infrared spectroscopy prediction is a rapid, inexpensive, highthroughput technique based on commonly used instruments that may be applied to milk samples that are already collected for other analyses. Thus, our analysis of FTIR calibrations suggests new applications for this technique in the dairy industry, especially for the monitoring of cheese-making processes and the valuation of milk for payment systems. In addition, the estimated prediction models can be used to provide breeding organizations with information on new phenotypes for cheese yield and milk nutrient recovery, potentially allowing these traits to be enhanced through selection.

\section{ACKNOWLEDGMENTS}

The authors thank the Autonomous Province of Trento for funding the project, the RISIB SMUPR project n. 4145 for the availability of the instruments of 
the NIRS-Food laboratory, and the Superbrown Consortium of Bolzano and Trento (Trento, Italy) for the support in sampling and recording activities. The authors also thank the editor and the reviewers for their useful comments.

\section{REFERENCES}

Afseth, N. K., H. Martens, Å. Randby, L. Gidskehaug, B. Narum, K. Jørgensen, S. Lien, and A. Kohler. 2010. Predicting the fatty acid composition of milk: A comparison of two Fourier transform infrared sampling techniques. Appl. Spectrosc. 64:700-707.

Aleandri, R., J. C. Schneider, and L. G. Buttazzoni. 1989. Evaluation of milk for cheese production based on milk characteristics and Formagraph measures. J. Dairy Sci. 72:1967-1975.

Ali, A. K. A., and G. E. Shook. 1980. An optimum transformation for somatic cell concentration in milk. J. Dairy Sci. 63:487-490.

Arnould, V. M.-R., H. Soyeurt, N. Gengler, F. G. Colinet, M. V. Georges, C. Bertozzi, D. Portetelle, and R. Renaville. 2009. Genetic analysis of lactoferrin content in bovine milk. J. Dairy Sci. 92:2151-2158.

Barbano, D. M., and J. M. Lynch. 2006. Major advances in testing of dairy products: Milk component and dairy product attribute testing. J. Dairy Sci. 89:1189-1194.

Bittante, G., and A. Cecchinato. 2013. Genetic analysis of the Fouriertransform infrared spectra of bovine milk with special emphasis to individual wavelengths related to specific chemical bonds. J. Dairy Sci. 96:5991-6006. http://dx.doi.org/10.3168/jds.2013-6583.

Bittante, G., C. Cipolat-Gotet, and A. Cecchinato. 2013. Genetic parameters of different measures of cheese yield and milk nutrient recovery from an individual model cheese-manufacturing process. J. Dairy Sci. 96:7966-7979.

Bittante, G., M. Penasa, and A. Cecchinato. 2012. Invited review: Genetics and modeling of milk coagulation properties. J. Dairy Sci. 95:6843-6870.

Bonfatti, V., G. Di Martino, and P. Carnier. 2011. Effectiveness of mid-infrared spectroscopy for the prediction of detailed protein composition and contents of protein genetic variants of individual milk of Simmental cows. J. Dairy Sci. 94:5776-5785.

Brandt, M., A. Haeussermann, and E. Hartung. 2010. Invited review: Technical solutions for analysis of milk constituents and abnormal milk. J. Dairy Sci. 93:427-436.

Cecchinato, A., C. Cipolat-Gotet, J. Casellas, M. Penasa, A. Rossoni, and G. Bittante. 2013. Genetic analysis of rennet coagulation time, curd-firming rate, and curd firmness assessed over an extended testing period using mechanical and near-infrared instruments. J. Dairy Sci. 96:50-62.

Cecchinato, A., M. De Marchi, L. Gallo, G. Bittante, and P. Carnier. 2009. Mid-infrared spectroscopy predictions as indicator traits in breeding programs for enhanced coagulation properties of milk. J. Dairy Sci. 92:5304-5313.

Cipolat-Gotet, C., A. Cecchinato, M. De Marchi, and G. Bittante. 2013. Factors affecting variation of different measures of cheese yield and milk nutrient recovery from an individual model cheesemanufacturing process. J. Dairy Sci. 96:7966-7979.

Cipolat-Gotet, C., A. Cecchinato, M. De Marchi, M. Penasa, and G. Bittante. 2012. Comparison between mechanical and near-infrared optical methods for assessing coagulation properties of bovine milk. J. Dairy Sci. 95:6806-6819.

Cologna, N., R. Dal Zotto, M. Penasa, L. Gallo, and G. Bittante. 2009. A laboratory micro-manufacturing method for assessing individual cheese yield. Ital. J. Anim. Sci. 8(Suppl. 2):393-395.

Couvreur, S., C. Hurtaud, P. G. Marnet, P. Faverdin, and J. L. Peyraud. 2007. Composition of milk fat from cows selected for milk fat globule size and offered either fresh pasture or a corn silage-based diet. J. Dairy Sci. 90:392-403.

Curley, D. M., T. F. Kumosinski, J. J. Unruh, and H. M. Farrell Jr. 1998. Changes in the secondary structure of bovine casein by
Fourier transform infrared spectroscopy: Effects of calcium and temperature. J. Dairy Sci. 81:3154-3162.

Dal Zotto, R., M. De Marchi, A. Cecchinato, M. Penasa, M. Cassandro, P. Carnier, L. Gallo, and G. Bittante. 2008. Reproducibility and repeatability of measures of milk coagulation properties and predictive ability of mid-infrared reflectance spectroscopy. J. Dairy Sci. 91:4103-4112.

De Marchi, M., M. Penasa, A. Cecchinato, M. Mele, P. Secchiari, and G. Bittante. 2011. Effectiveness of mid-infrared spectroscopy to predict fatty acid composition of Brown Swiss bovine milk. Animal 5:1653-1658.

Emmons, D. B., C. A. Ernstrom, C. Lacroix, and P. Sauvé. 1993. Further consideration in formulas for predicting cheese yield from the composition of milk. J. Dairy Sci. 76:914-920.

Emmons, D. B., C. A. Ernstrom, C. Lacroix, and P. Verret. 1990. Predictive formulas for yield of cheese from composition of milk a review. J. Dairy Sci. 73:1365-1394.

Emmons, D. B., and H. W. Modler. 2010. Invited review: A commentary on predictive cheese yield formulas. J. Dairy Sci. 93:55175537.

Etzion, Y., R. Linker, U. Cogan, and I. Shmulevich. 2004. Determination of protein concentration in raw milk by mid-infrared Fourier transform infrared/attenuated total reflectance spectroscopy. J. Dairy Sci. 87:2779-2788.

Fagan, C. C., M. Castillo, C. P. O'Donnell, D. J. O'Callaghan, and F. A. Payne. 2008. On-line prediction of cheese making indices using backscatter of near infrared light. Int. Dairy J. 18:120-128.

Fagan, C. C., M. Castillo, F. A. Payne, C. P. O'Donnell, M. Leedy, and D. J. O'Callaghan. 2007a. Novel online sensor technology for continuous monitoring of milk coagulation and whey separation in cheesemaking. J. Agric. Food Chem. 55:8836-8844.

Fagan, C. C., M. Leedy, M. Castillo, F. A. Payne, C. P. O'Donnell, and D. J. O'Callaghan. 2007b. Development of light scatter sensor technology for on-line monitoring of milk coagulation and whey separation. J. Food Eng. 83:61-67.

Fenelon, M. A., and T. P. Guinee. 1999. The effect of milk fat on Cheddar cheese yield and its prediction, using modifications of the Van Slyke cheese yield formula. J. Dairy Sci. 82:2287-2299.

Hewavitharana, A. K., and B. van Brakel. 1997. Fourier transform infrared spectrometric method for the rapid determination of casein in raw milk. Analyst (Lond.) 122:701-704.

Hicks, C. L., J. O'Leary, and B. E. Langlois. 1981. Equipment and procedure for manufacturing laboratory cheese curd. J. Dairy Sci. 64:523-525.

Hurtaud, C., H. Rulquin, M. Delaite, and R. Verite. 1995. Appreciation de l'aptitude fromagere des laits de vacches individuels. Tests d'aptitude fromagere et rendement fromager de fabrication. Ann. Zootech. 44:385-398.

International Committee for Animal Recording (ICAR). 2012. International agreement of recording practices - Guidelines approved by the general assembly held in Cork, Ireland on June 2012. ICAR. Rome, Italy.

Johnson, M. E., C. M. Chen, and J. J. Jaeggi. 2001. Effect of rennet coagulation time on composition, yield, and quality of reduced-fat Cheddar cheese. J. Dairy Sci. 84:1027-1033.

Karoui, R., G. Downey, and C. Blecker. 2010. Mid-infrared spectroscopy coupled with chemometrics: A tool for the analysis of intact food systems and the exploration of their molecular structure Quality relationships - A review. Chem. Rev. 110:6144-6168.

Karoui, R., M. Hammami, H. Rouissi, and C. Blecker. 2011. Mid infrared and fluorescence spectroscopies coupled with factorial discriminant analysis technique to identify sheep milk from different feeding systems. Food Chem. 127:743-748.

Karoui, R., A. M. Mouazen, E. Dufour, L. Pillonel, D. Picque, J. De Baerdemaeker, and J.-O. Bosset. 2006. Application of the MIR for the determination of some chemical parameters in European Emmental cheeses produced during summer. Eur. Food Res. Technol. 222:165-170.

Kaylegian, K. E., D. A. Dwyer, J. M. Lynch, D. E. Bauman, J. R. Fleming, and D. M. Barbano. 2009. Impact of fatty acid composi- 
tion on the accuracy of mid-infrared fat analysis of farm milks. J. Dairy Sci. 92:2502-2513.

Kaylegian, K. E., G. E. Houghton, J. M. Lynch, J. R. Fleming, and D. M. Barbano. 2006. Calibration of infrared milk analyzers: Modified milk versus producer milk. J. Dairy Sci. 89:2817-2832.

Leitner, G., Y. Lavi, U. Merin, L. Lemberskiy-Kuzin, and G. Katz. 2011. Online evaluation of milk quality according to coagulation properties for its optimal distribution for industrial applications. J. Dairy Sci. 94:2923-2932.

Lynch, J. M., D. M. Barbano, M. Schweisthal, and J. R. Fleming. 2006. Precalibration evaluation procedures for mid-infrared milk analyzers. J. Dairy Sci. 89:2761-2774.

Malacarne, M., A. Summer, E. Fossa, P. Formaggioni, P. Franceschi, M. Pecorari, and P. Mariani. 2006. Composition, coagulation properties and Parmigiano-Reggiano cheese yield of Italian Brown and Italian Friesian herd milks. J. Dairy Res. 73:171-177.

Melilli, C., J. M. Lynch, S. Carpino, D. M. Barbano, G. Licitra, and A. Cappa. 2002. An empirical method for prediction of cheese yield. J. Dairy Sci. 85:2699-2704.

O'Callaghan, D. J., C. P. O'Donnell, and F. A. Payne. 2002. Review of systems for monitoring curd setting during cheesemaking. Int. J. Dairy Technol. 55:65-74.

Rutten, M. J. M., H. Bovenhuis, J. M. L. Heck, and J. A. M. van Arendonk. 2011. Predicting bovine milk protein composition based on Fourier transform infrared spectra. J. Dairy Sci. 94:5683-5690.
Rutten, M. J. M., H. Bovenhuis, K. A. Hettinga, H. J. F. van Valenberg, and J. A. M. van Arendonk. 2009. Predicting bovine milk fat composition using infrared spectroscopy based on milk samples collected in winter and summer. J. Dairy Sci. 92:6202-6209.

Rutten, M. J. M., H. Bovenhuis, and J. A. M. van Arendonk. 2010. The effect of the number of observations used for Fourier transform infrared model calibration for bovine milk fat composition on the estimated genetic parameters of the predicted data. J. Dairy Sci. 93:4872-4882.

Soyeurt, H., P. Dardenne, F. Dehareng, G. Lognay, D. Veselko, M. Marlier, C. Bertozzi, P. Mayeres, and N. Gengler. 2006. Estimating fatty acid content in cow milk using mid-infrared spectrometry. J. Dairy Sci. 89:3690-3695.

Soyeurt, H., F. Dehareng, N. Gengler, S. McParland, E. Wall, D. P Berry, and M. Coffey. 2011. Mid-infrared prediction of bovine milk fatty acids across multiple breeds, production systems, and countries. J. Dairy Sci. 94:1657-1667.

Van Der Ven, C. S. Muresan, H. Gruppen, D. B. A. De Bont, K. B. Merck, and A. G. J. Voragen. 2002. FTIR spectra of whey and casein hydrolysates in relation to their functional properties. J. Agric. Food Chem. 50:6943-6950.

Wedholm, A., L. B. Larsen, H. Lindmark-Mansson, A. H. Karlsson, and A. Andren. 2006. Effect of protein composition on the cheesemaking properties of milk from individual dairy cows. J. Dairy Sci. 89:3296-3305. 